\title{
Study on the Curriculum Construction of Applied Civil Engineering Specialty in Local Universities
}

\author{
Wang $\mathrm{Li}^{\mathrm{a}}$, Shi Xiaoxing ${ }^{\mathrm{b}}$, Zhang Chunyang ${ }^{\mathrm{c}}$, Lv Ping ${ }^{\mathrm{d}}$ \\ College of Civil Engineering, Baicheng Normal University, Baicheng, 137000,China

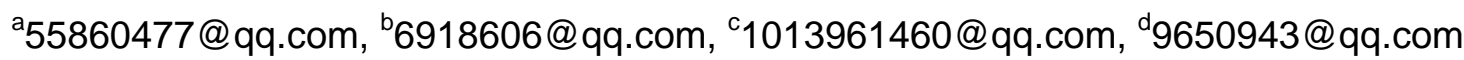

\section{Keywords: Local Universities, Civil Engineering, Curriculum Construction}

\begin{abstract}
In order to obtain good results in the construction of geotechnical engineering courses, it requires local universities to conduct in-depth analysis of the characteristics in colleges and universities, and it needs to carry out the construction of applied civil engineering courses. In the concrete construction process, it is necessary for teachers to strengthen the students occupation quality and application ability, and it can achieve good teaching effect. This paper focuses on the curriculum in local university civil engineering construction work .
\end{abstract}

\section{Introduction}

With the continuous reform of China's education system, the construction of civil engineering course in local colleges and universities need higher requirements. In the setting of specialized courses, schools need to fully reflect the professional specialized, targeted, practical and industry. Only in this way, we can make local colleges to cultivate in the face of a number of high-quality talents of local, and promote local economic and social development further.

\section{A Brief Analysis of the Construction of Applied Civil Engineering Courses}

Local colleges training courses in Applied Civil Engineering aims to train a number of adaptation to regional economic and social development needs, and mastered the theoretical knowledge of civil engineering disciplines and applied basic knowledge of talent, it also requires the students to have certain innovation ability and development ability of a core. The contents and construction of curriculum system for training talent, it also requires local colleges to pay enough attention to this problem, and can fully guarantee the rationality and scientificity of the professional curriculum construction work. But at this stage there are many local universities in the construction of curriculum system in the process, still apply the teaching course system of research university and its teaching emphasis also is placed on the analysis of engineering structure and design, practice and unable to effectively cultivate students In addition, some local colleges and universities. In the course of construction of civil engineering course in the engineering application of too much emphasis on teaching, the curriculum is also the engineering design and construction management software, and is completely according to the skills training mode. In this mode of teaching, students' creative thinking can not be very good ascension, and it is difficult to meet the actual needs of the region for applied talents of civil engineering[1].

So in the process of civil engineering specialty, it also need to cultivate students' practice ability as an important basis for the development of the situation and goals. In combination with the development of the region as well as the characteristics of the construction industry, to form a theory of "teaching" as the basis for teaching, to "innovation practice" as a multi system the purpose of teaching, the training mode of the multi module personnel.

\section{Measures to Strengthen the Construction of Applied Civil Engineering Courses in Local Universities}

To Cultivate Students' Occupation Quality in the Teaching Process. Applied undergraduate education is a teaching mode with the popularization of higher education development. In the 
development process of the popularization of higher education in the engineering curriculum and curriculum of undergraduate occupation have also entered the classroom, and the occupation education of different types also have a certain degree of development. Therefore, China the local colleges in the process of cultivating applied talents, also need to strengthen the practical teaching work, and asked the graduates to practice after a period of time after the effective solution to the problems appeared in the first production line, which will own a variety of theoretical knowledge learned into practice practical ability, and provide a large amount of highly skilled talents for the further development of China's construction industry[2].

Applied talents of civil engineering professional after graduation is more engaged in civil engineering design or construction units in the survey and Design Institute, construction and other related technical management. Graduates after the inspection of the actual project, through the national registration and qualification examination, can become a national registered structural engineers, architects and engineers other specialized personnel. Therefore also need training mode in the applied undergraduate talents and have more than one occupation registration certificate "the occupation characteristics are linked, and the need to attach importance to the work of occupation quality education to the students in the daily teaching process. Only the occupation education throughout all aspects of the teaching., can let the students have a clear understanding for their occupation, and help students develop good occupation in Strengthen the training of the students quality. Through the occupation quality model, it can also make students' learning initiative has been improved, and can make the students actively participate in the learning process and the related knowledge. In the civil engineering profession needs related to the cost of staff, supervisors, engineers and construction workers in the qualification certificate and so also, it requires teachers to the contents of the certificate to carry out targeted training in practical teaching, and help students enhance their certificate to obtain rates. In addition to local colleges and universities to build a double qualified teachers, and also need to strengthen the theory teaching and practice teaching of the two the teaching work, to be able to obtain the good teaching effect.

School Enterprise Cooperation and Setting up Local Characteristic Courses. Part of the present application-oriented colleges applied talents through school enterprise cooperation mode. The mode of school enterprise cooperation to be able to make development of local universities on application-oriented colleges, and can be based on the needs of the local economic and social development, cultivating a number of applied high level. Therefore in the process of training applied talents in civil engineering, also requires universities to adhere to the professional setting to the forefront of the market, and to seize the local economic construction and local economic and social development for the actual demand of talents. The need to combine the teaching resources of the local government and industry enterprises, industries and enterprises to realize the sharing of teaching resources together, establish training bases. In the process of the construction of professional courses, only allow local enterprises to fully participate in the personnel training and The whole process of curriculum construction, and the importance of enterprises in the industry, the school curriculum construction in full play an important role, it can make the enterprise in the school in the process of the construction into full play, and makes the applied talents of civil engineering training can fully meet the actual development needs of various enterprises. In addition to colleges and universities the investigation and understanding of the professional knowledge and knowledge structure of a reasonable proportion of the employer, and will need the process as a guide, on the basis of training work oriented curriculum system.

Paying Attention to the Construction of Practice Teaching System. Cultivation of applied talents in local colleges undergraduate civil engineering professional training will also need to focus placed on the students practical ability[3]. In order to achieve good practice ability, requires universities to strengthen their own practice curriculum system construction work. In civil engineering involves the knowledge once more, the curriculum design unreasonable situation, also it is easy to cause the practice course become simple skills of repetitive work, and cannot be related to the consolidation of theoretical knowledge in the practice teaching process. So that in the design process of the curriculum system will also need to deepen the theoretical knowledge as an important 
teaching goal, and then let the students can also in the process of practice of the reform, so as to make students' learning initiative can be improved, and achieved good learning effect.

Reform of experiment teaching: for students of civil engineering specialty, they need to have a good practical ability and practical ability. So in the process of practice teaching also need to pay more attention to the students of engineering application and innovation ability. In the experiment teaching process generally requires comprehensive design experimental comparison, verification experiment content the relatively simple, and have a certain degree of independence, it is difficult to effectively stimulate students interest in learning. So in the process of experiment teaching also can to carry out experimental teaching activities carried out in the comprehensive design verification teaching foundation, then a single engineering experiment focused on a comprehensive engineering project in the experiment. In the comprehensive design experiment process requires teachers only on experimental objectives and key points to the request, and the students' experiment Operation guide, and in the process of experiment in give full play to students' subject status. Through the comprehensive design experimental teaching, students not only need to test the basic framework recommended by teachers, but also need to break the framework based on full verification. Teachers also need to encourage students to carry out experimental work different experimental procedures through a variety of ways, also need to actively encourage students to choose the engineering experiment object. In addition in the practice teaching process with an experimental project, teachers also need to allow students from different experimental methods to solve this problem by, and on the basis of students' innovation ability and practice ability has been further improved.

The traditional verification experiment also requires local universities to optimize and design continuously, and needs to be the practical engineering problem as the background, the specific subjects and experimental data should come from the project site. The work of experimental verification in this context, also can let the students master the basic theory of effective on the knowledge, also can let their ability to solve practical engineering problems can be improved. For example, in soil mechanics and foundation of the experimental teaching process, teachers can be based on introducing the actual project of teaching, and the students according to the distribution of soil exploration site and soil sampling come on, the basic physical parameters of the soil are reasonably determined[4].

The practice of reform: in the teaching plan of civil engineering in general will also arrange the practice, production practice, graduation practice and internship process measurement more. The curriculum design, but also need to involve the construction drawing budget, design of concrete structure and steel structure design and other content. But the general practice training in local colleges in the process, mostly by professional teachers to contact or internships, and then lead the students to learn in internships, and invite the appropriate engineering personnel to practice knowledge explanation. Then let the students practice work at the site, at the end of the internship report after students need writing and submission, and as a result the evaluation method of production practice. But the training mode of funds still exist in the application process Tension, contact difficulties and internship students to practice the process is not serious problems, so local universities also need in the process of curriculum construction of civil, to continue to strengthen the construction of practice base. Through the construction of practice base, to ensure the production practice students smoothly, and through local enterprises stable cooperative relations can also make the practice site selection and preparations before practice can have a good condition, so as to lay a good foundation for practice teaching[5].

Secondly, universities also need to actively promote the autonomous decentralized practice, contact the students are required to practice internship and internship units according to the relevant requirements of the task book guide in the book, and can be free to extend the practice time, the only way to help students acquire good practice effect, also can create certain economic benefits for the relevant internship units. In the practice, students can also directly accept to practice a series of practical problems existing in the process, and can let the students for civil engineering problem solving ability is improved. Finally, universities also need to further strengthen the internship requirements, students are required to write have internship diaries and internship report, and it 
needs to be as an important basis for evaluating students achievement. In the concrete Learning process, students were required to strictly in accordance with the relevant requirements of the internship program to carry out a series of practice activities, and in combination with its own practice content, to help text and graphics mode on the record during the internship period. For example, the technical and economic effect, structural arrangement in Civil Engineering and construction operation essentials and so on. It can help the students to have a clearer understanding of the practical problems in the process, and to their own practical ability and innovation ability improve. The only way to achieve good results of the practice, to meet the specific needs for civil engineering talents local enterprises.

\section{Conclusion}

Local universities need to cultivate a group of professional disciplines to master the theoretical knowledge and basic knowledge of the outstanding talents of civil engineering in the process of the construction of application oriented civil professional courses, these factors are based on regional economic and social development and the combination of the local economic construction and social development needs are the foundation of. And only the school build a reasonable and effective curriculum system, it can ensure the quality of personnel training, and provide talents reserve enough and for the development of the regional civil industry, so as it can promote the further development of civil engineering construction industry in our country.

\section{References}

[1]HE Yuliang, WU Xudong, GAO Yueqing.The construction of civil engineering specialty in local universities under the background of building modernization -- Taking Shaoxing University as an example[J].Journal of Shaoxing University,2016,36(11):9-13.

[2]LIU Zhiyong,JIANG Hui,NIU Honglei.Exploration and practice of innovative applied talents training in Civil Engineering Specialty -- Taking Xuzhou Institute of technology as an example[J].Journal of Architectural Education in Institutions of Higher Learning,2015,24(1):22-25.

[3]WANG Yinhui,PENG Wei,WANG Juandi.Selection and construction of core supporting courses for applied undergraduates of civil engineering[J].Science and Technology Innovation Herald,2014,(18):227-228.

[4]GU Yanling,SUN Jiaguo.Exploration on the training mode of Applied Undergraduate Talents in Civil Engineering Specialty[J].Science and Technology of West China,2011,10(20):70-71,92.

[5]TONG Huaifeng.Discussion on curriculum construction and teaching of soil mechanics under the mode of training applied talents[J].China Educational Technology \& Equipment, 2014, (16):103-104. 